\title{
The rise of shari'a by-laws in Indonesian districts
}

\section{An indication for changing patterns of power accumulation and political corruption}

\author{
Michael Buehler
}

\begin{abstract}
A rising number of districts in Indonesia have adopted shari'a by-laws in recent years. This article shows that this development has to be situated in the context of institutional change. Shari'a by-laws allow regents to open up new revenue streams. These revenues are then used to consolidate political power.
\end{abstract}

Keywords: democratization; decentralization; elections; political corruption; zakat; Islam; Indonesia

In recent years, a growing number of district governments in Indonesia (that is, below the provincial level) have adopted shari'a by-laws. ${ }^{1}$ Proponents of such by-laws ${ }^{2}$ argue that they are needed to tackle the many problems Indonesian districts face. Preventing ills such as gambling,

1 The most recent studies on shari' a by-laws in Indonesia paint a somewhat contradictory picture. While a World Bank study reports a steady increase in shari' a by-laws since the trend started in 2001 after the adoption of Regional Governance Law No 22/1999 the same year (World Bank, 2007), the Asia Foundation reports a dramatic decline in the adoption of new shari' a by-laws since the peak year of 2003. In 2007, not a single shari'a by-law was adopted in the entire archipelago, according to the study, which is based on various data sources (Bush, 2007, p 2). However, as many districts do not report their new by-laws to central government, the databases used in the Asia Foundation study most likely underreport the actual number of by-laws adopted, including shari' a-inspired local regulations. During a research trip to South Sulawesi province in November 2007, the author found a new shari'a-inspired bylaw recently adopted by the provincial parliament. Additionally, two shari' a by-laws are waiting to be ratified by district assemblies in 2008 .

2 Although the first Regional Governance Law (No 22/1999) placed religious affairs under the authority of central government, regents were given the authority to issue by-laws on other matters. This legal loophole allows district governments to adopt shari'a by-laws. Shari'a by-laws are thus often called perda shari'a Islam, which translates as 'Islamic regional regulation'. 
prostitution or the consumption of alcohol, shari' a by-laws should curb crime at the local level. Opponents of such by-laws have accused the shari' a movement of pursuing symbolist politics that fail to address the real problems of Indonesian districts. Shari'a by-laws, these critics argue, are adopted by political elites, simply 'to overcome serious legitimacy problems, particularly given increasing public identification of the local political class with corruption and unethical rent-seeking' (McGibbon, 2006, p 334).

This article suggests a somewhat different view of the phenomenon. The increasing number of Indonesian district governments that have adopted shari'a-motivated regulations in recent years is not just an indication of a conservative movement within the Indonesian Muslim community; nor can the development be simply reduced to symbolist politics. Rather, shari'a by-laws indicate changing patterns of power accumulation and political corruption in Indonesian local politics. The following paragraphs show that shari'a by-laws allow local elites to gain political currency by opening up new sources of revenue that were previously beyond their reach. Revenues generated by shari' a by-laws are then used to establish and nurture private networks of power brokers at the subdistrict level.

These developments have to be situated in the context of institutional change since the demise of the New Order in 1998, namely the introduction of direct elections for regents, which were held for the first time in 2005. These elections have given true power to the population and changed the logics of power accumulation for regents in Indonesian districts. Most immediately obvious, local political elites now have to 'work' the electorate more closely and regularly than ever before to gain access to and remain in power. ${ }^{3}$ The article argues that shari' a by-laws indicate the rise of machine politics at the local level in Indonesia, a form of political corruption that contrasts with patterns of political corruption typical of monarchical or military-bureaucratic regimes (Scott, 1972, p 93). The popularity of shari'a by-laws is thus a sign of broader change in the patterns of power accumulation and political corruption in post-New Order Indonesia.

To illustrate this point, the article analyses the shari'a by-laws in several districts of South Sulawesi province in eastern Indonesia. The number of districts in South Sulawesi province that have adopted shari'a by-laws is only topped by Aceh province, which has adopted shari'a

See Buehler, 2007 on the importance of local personal networks in regents' elections. 
by-laws in the entire province under its special autonomy status. ${ }^{4}$ South Sulawesi, in short, has the highest number of districts that have adopted shari'a-inspired by-laws of all provinces lacking special autonomy status. ${ }^{5}$

\section{Opening up new sources of revenue}

Many of the shari'a by-laws implemented in South Sulawesi province since 2001 are seemingly of a rather symbolic nature. For example, Bulukumba regency, ${ }^{6}$ located in the south-east of the province, adopted a regulation in 2003 making it mandatory for schoolgirls to wear a headscarf (Peraturan Kabupaten Daerah Bulukumba No 5/Tahun 2003, Bab 1, Pasal 6). The regulation further requires men working in both the private sector and the government bureaucracy to wear long trousers when at the office (Peraturan Kabupaten Daerah Bulukumba No 5/Tahun 2003, Bab 1, Pasal 7, A, Ayat 1), while women are now obliged by law to wear skirts that reach their ankles when at work (Peraturan Kabupaten Daerah Bulukumba No 5/Tahun 2003, Pasal 7, B, Ayat 2).

The Bulukumba regent also adopted a by-law requiring students and schoolchildren to be able to read the Qur'an to 'a satisfactory level' if they wanted to pass their final exams (Peraturan Kabupaten Daerah Bulukumba No 6/Tahun 2003 Bab 3, Pasal 7). The same regulation made satisfactory Qu'ran reading ability a criterion to become a district bureaucrat. ${ }^{7}$ Promotions within the bureaucracy now also depend

4 For the history and recent developments of political Islam in Aceh, see Aspinall, 2007. For a fine essay on the current politics of shari'a in Aceh, see Aspinall, 2008.

5 At the time of writing in November 2007, Indonesia had a total of 33 provinces, four of which had special autonomy status, namely Aceh, Jakarta, Papua andYogjakarta.

6 Bulukumba regency had a pioneering role in the implementation of shari' a by-laws in the province due to its very active regent Patabai Pabokori, a member of the Preparatory Committee for the Implementation of Islamic Law (KPPSI - Komite Persiapan Penegakan Syariat Islam), a movement that strives for the implementation of shari'a by-laws in the entire province. Bulukumba, therefore, often serves as a model for the implementation of shari'a by-laws in other districts of South Sulawesi province. Patabai Pabokori is currently the Head of the Education Department for South Sulawesi (Kepala Dinas Pendidikan Sulawesi Selatan) and has started to issue by-laws increasing the amount of religious teaching in the curriculum for primary schools in the entire province.

7 In July 2006, for example, a local newspaper ran an article reporting that in Bulukumba, 191 candidates aspiring to become local bureaucrats had to pass a test in Qur'an reading. Three people failed and were given a week to learn to read the Qur'an in Arabic, after which they were tested again. The article also showed a picture of an 
on Qur'an reading skills (Peraturan Kabupaten Daerah Bulukumba No 6/Tahun 2003). ${ }^{8}$ Patabai Pabokori, the then regent who initiated all these new by-laws, further conducted a 'Crash Programme in Religiosity' (Crash Program Keagamaan [sic]) for his district, during which he distributed 'degrees' for outstanding Qur' an reading abilites to 'students' wearing 'graduation uniforms', and had small children recite from the Qur'an in Arabic. The regent further distributed money to schoolteachers in the district and had bottles of alcohol publicly destroyed by a steamroller (Patabai Pabokori, 2005, pp 128-133).

\section{New regulations on alms: national-level ambiguity allows regents to adopt by-laws}

There are shari' a by-laws, however, which go beyond mere symbolism and serve more concrete interests of local politicians. It is such by-laws with which this article is concerned. Most important in that respect are the by-laws on zakat that have been adopted by many districts in South Sulawesi province in recent years. 'Zakat is an obligation of Muslims to give a specific amount of their wealth - with certain conditions and requirements - to beneficiaries called almustahiqqin' (Alfitri, 2006, p 57). ${ }^{9}$ This obligation outlined in the

ustadz [religious notable] supervising the Qur'an reading test at the regent's office (Fajar, 4 July 2006, p 29). In an interview conducted in November 2007 with Amin Syam, then governor of South Sulawesi province, he stated that his government had designed a course for bureaucrats that allowed state officials to become fluent in Arabic within just nine hours. Therefore, no bureaucrat in the provincial administration should be afraid of failing the Arabic test (Amin Syam, 2007).

8 Other regents have implemented similar by-laws. In Pangkep regency, for example, every district bureaucrat now has to attend 'religious training' once a year. During this training, all members of the district administration have to live in Pesantren Marang, a religious boarding school, for three days (Pedoman Rakyat, 31 July 2006, p 19).

9 'There are two types of zakat in Islam: a flat fee imposed on each person, called zakat al-fitr, and a tax on wealth, called zakat al-mal. Zakat al-fitr refers to the obligation of every Muslim (except those who are absolutely destitute) to contribute a certain amount of staple food or pay an equivalent monetary amount in the month of Ramadan before the Muslim festive season celebration known as Ied al-Fitr. The zakat al-fitr flat fee is one sa' - a little more than two kilograms of wheat, barley, dates, or rice-or the monetary equivalent. All Muslims - including the poor, as long as they will still have food for the first day of Ied al-Fitr - must pay zakat al-fitr for themselves and their dependents. The proceeds are devoted to helping feed the needy during the Ied al-Fitr celebration. Accordingly, even though many have-nots must pay zakat-al fitr, they are also the major recipient of the proceeds. In practice, payers usually give zakat al-fitr directly to beneficiaries without interference from the state or any other third party. Unlike zakat al-fitr, zakat al-mal is levied only on Muslims whose wealth exceeds a threshold called nisab. Before nisab is calculated, the basic needs of the payer and his family, as well as their 
Qu'ran originates in Islam's strong concern with social and economic justice. ${ }^{10}$

It was not until the demise of the Suharto regime in 1998, however, that the Indonesian government promulgated the comprehensive Law on Zakat Management (No 38/1999), which regulated the involvement of the state in zakat collection more coherently (Warta Perundangan, 18 October 1999, p 1). ${ }^{11}$ The adoption of the Law on Zakat Management No 38/1999 during Habibie's presidency was regarded as an important political achievement by those Muslim groups that longed for a closer relationship between the Indonesian state and Islam (Salim, 2003, p 218). However, the law was drafted hastily, and Habibie probably did not intend it to be more than a populist move to secure broad support from the Muslim community ahead of presidential elections. ${ }^{12}$

financial obligations and debts due, are taken into account...Those requirements distinguish zakat al-mal from zakat al-fitr, and enable zakat al-mal to be regulated by the state much like a tax' (Alfitri, 2006, p 58).

See Davis and Robinson, 2006.

11 Political elites in Indonesia traditionally had a rather ambiguous attitude towards zakat collection and distribution, which had historical origins. In the nineteenth century, the embezzlement of zakat revenues by members of the Dutch colonial bureaucracy was widespread. In nineteenth century West Java, zakat al-fitr was mainly paid to religious teachers, so-called kiayi or village Qur'an teachers. In East Java, zakat al-mal was under the jurisdiction of the kiayi or other religious notables (ulama), while zakat al-fitr was given to religious notables at the village level, including preachers (khatibs) and other official staff working at the mosques. The main difference, however, was that in East Java neither zakat al-fitr nor zakat al-mal was collected by government bodies (amil) established for this purpose, while in West Java 'specially appointed religious functionaries exercised the role of amil, and these were in turn under the direct supervision of the so-called native chiefs in their respective administrative division' (Salim, 2003, p 183). Unsurprisingly, it was from the regions of West Java that the colonial government received the highest number of reports of misuse of zakat funds (Salim, 2003, p 183). Against this backdrop, the colonial government feared that the misuse of zakat by its appointees would eventually undermine its own authority. In 1893, the government of the then Netherlands Indies issued a regulation aimed at preventing such behaviour. In 1905, the government reiterated its determination to go against such practices, when it issued another regulation, Bijblad 6200, which explicitly prohibited native officials from being involved in zakat management. Since the beginning of the twentieth century, then, the Indonesian government has made a clear distinction between the state and the Muslim community's affairs regarding religious matters (Salim, 2003, p 183).

12 Due to the rushed drafting and implementation of this law, it is full of shortcomings. For example, the law fails to specify the calculation of nisab, the threshold for zakatal mal payments mentioned above, along with the exact time of payment for zakat. The law states that such matters should simply follow Islamic law as outlined in the Qur'an (Alfitri, 2006, p 63). Law on Zakat Management No 38/1999 was also in conflict with the Law on Income Tax No 17/2000 (amending the Law on Income Tax No 7/1983), on which more below. 
Nevertheless, the Law on Zakat Management No 38/1999 established rules for Government Zakat Collection Bodies (BAZ - Badan Amil Zakat) and Private Zakat Collection Bodies (LAZ - Lembaga Amil Zakat) to collect and distribute both zakat al-mal and zakat al-fitr. ${ }^{13} \mathrm{~A}$ subsequent decree by the Ministry of Religion, MRD No 581/1999, detailed the organizational structures and specified broad competencies for BAZ. It also issued conditions that LAZ had to fulfil in order to be officially approved as zakat collection institutions.

However, neither the national zakat law nor the ministerial decree specified rules on how to collect zakat (Alfitri, 2006, p 64). More importantly, the Law on Zakat Management No 38/1999 did not make zakat payments obligatory, unlike similar laws in other Muslim countries. Leaving it up to Muslims whether they paid zakat or not, the Indonesian state at the national level adopted a somehow 'neutral position with regard to the scope and the obligatory nature of zakat' (Alfitri, 2006, p 63). It was this failure of central government to issue clear regulations on the actual collection process for zakat and its hesitant position vis-à-vis the obligatory nature of zakat collection that worked to the advantage of regents.

\section{Regulating the collection of zakat and making zakat payments mandatory}

Local shari'a by-laws on zakat have two main characteristics. The first concerns regulation of the collection process. Regents in several districts of South Sulawesi used shari'a by-laws to bring the collection of zakat under their control. A by-law in Bulukumba regency, for example, explicitly states that the collection of zakat falls under the authority of the local government zakat collection body, BAZ (Peraturan Kabupaten Daerah Bulukumba, No 2/2003, Bab 8, Pasal 22-26). Most districts in the province that adopted shari'a by-laws followed the example of Bulukumba and gave BAZ far-reaching autonomy in collecting zakat.

While, theoretically, the national zakat law ruled BAZ to be independent from local government intervention, this was rarely the case in practice. In Barru district in South Sulawesi, for example, Muhammad Rum, the regent, stated in an interview that, based on a regulation he had issued, BAZ would receive money from the district budget (APBD

13 The law primarily outlined clear regulations for BAZ, while it failed to do so for LAZ (Alfitri, 2006, p 65; Salim, 2003, p 219). It thus empowered BAZ vis-à-vis LAZ. 
- Anggaran Pendapatan dan Belanja Daerah) to pay the 'operational costs' and salaries of BAZ personnel (Rum, 2006). The regent further stated that he was also consulted on the appointment of board members of the zakat collection body. Likewise, a shari' a by-law on zakat adopted in Makassar, the provincial capital, ruled that either the mayor or the head of the city's religious department would appoint the board members [pengurus] of BAZ in the capital (Peraturan Daerah Kota Makassar, No 5/Tahun 2006, Bab 8, Pasal 14, Alat 1). ${ }^{14}$

Regents have also used shari' a by-laws to extend their control over the collection of zakat money outside the immediate reach of the government-controlled zakat collection body mentioned above. The shari'a by-law on zakat in Bulukumba regency, for example, ruled that the final appointment [pengukuhan] of private zakat collection bodies in the district (LAZ) should fall under the authority of the regent (Peraturan Kabupaten Daerah Bulukumba No 2/2003, Bab 5, Pasal 13, Ayat 1). ${ }^{15}$

The second and no less important characteristic of zakat by-laws issued by regents is that they made the payment of both zakat al-fitr and zakat al-mal mandatory for the population in their jurisdiction. In Bulukumba regency in South Sulawesi, for example, the local regulation on the collection of zakat ruled that 'all Muslim people, who are working... [have to pay zakat] after paying taxes' (Peraturan Kabupaten Daerah Bulukumba No 2/2003, Bab 7, Pasal 16). ${ }^{16}$ Furthermore, all Muslims going on the pilgrimage to Mecca in a given year are obliged to pay $1 \%$ of the costs of the pilgrimage to the government zakat collection body, BAZ (Peraturan Kabupaten Daerah Bulukumba No 2/ 2003, Bab 7, Pasal 19, Pasal 20 Ayat 1-4). ${ }^{17}$ The local by-law on zakat

14 While such regulations are in conflict with the national law, they also directly contradict the ruling on zakat laid down in the Qur'an itself, in which it is stated that the management of zakat should be financially self-sustaining and that zakat collectors are to be paid from zakat revenues. 'Those who collect and distribute zakat al-mal are paid from zakat proceeds. Zakat collectors are among the zakat al-mal beneficiaries in Islam. Hence, imposing the obligation of collecting and distributing zakat on the state does not burden the...budget' (Alfitri, 2006, p 58).

15 According to the by-law, the head of the district's department of religion is supposed to suggest possible private zakat collection bodies (LAZ) in a list to be handed in to the district government. Final approval is then given by the regent based on this list.

16 'Zakat profesi dikeluarkan atau disisihkan dari pendapatan seorang muslim yang bekerja atau berprofesi setelah dikeluarkan pajak' (Perda No 2/2003, Bab 7, Pasal 16).

17 Fees imposed on haj pilgrims as well as the rather mundane rationales behind them are not really new in Indonesia. In 1978, President Suharto himself imposed a fee on haji. The money obtained was then used by him and his entourage for 'tactical funds' usually dispersed in the context of elections (Amal, 1992, p 166). Interestingly, the 
Table 1. Mandatory monthly infaq and sadaqah payments for civil servants, by rank.

\section{Bureaucratic rank}

Class I

Class II

Class III

Class IV

Government official [Pejabat Negara]
Monthly payment in Indonesian Rupiah (IDR)*

Bulukumba district

City of Makassar

$$
\begin{aligned}
& 1,500 \\
& 3,000 \\
& 4,000 \\
& 5,000 \\
& 7,000
\end{aligned}
$$

Source: Perda Kabupaten Bulukumba No 2/2003, Bab IV, Pasal 20; Tentang

Pembentukan Unit Pengumpul Zakat, Instruksi Walikota Makassar No 02/451.12.05/ Inst/2007.

*IDR 10,000 equalled US\$1.09 at the time of writing in November 2007.

further ruled that the working population of Bulukumba was obliged to pay infaq and sadaqah, payments to poor Muslims, which the Qur'an actually specifies as voluntary. Every Muslim in Bulukumba district was charged IDR1,500 per month (approximately US cents 15) for infaq and sadaqah at the time of writing

\section{Targeting bureaucracies and private sector enterprises}

The most immediate target of such by-laws were local bureaucrats. Members of the district bureaucracy in Bulukumba, for example, were requested to pay $2.5 \%$ of their annual salary towards zakat. Additionally, staff of the local bureaucracy are obliged to pay infaq and sadaqah, the exact amount depending on their bureaucratic rank see Table 1. Similarly, in the provincial capital Makassar, a shari'a by-law on zakat collection, followed by a mayoral instruction, imposed analogous regulations on the city administration (Peraturan Walikota Makassar No 3/Tahun 2007; Instruksi Walikota Makassar No 02/451.12.05./Inst/2007). In both jurisdictions, the amounts outlined in the shari' a by-laws are directly deducted from the bureaucrats' salaries.

In several cases, shari'a by-laws on zakat were also adopted to gain

number of pilgrims from Bulukumba regency going to Saudi Arabia has declined sharply since 2003, the year the aforementioned by-laws on zakat were adopted. While in 2003, a total of 1,600 pilgrims from Bulukumba regency made the journey to Mecca, this number dropped to 637 in 2005 (Badan Pusat Statistik Sulawesi Selatan, 2005 , p 104). One can only speculate whether this relates to the shari'a by-law described above, which imposed a $1 \%$ tax on the costs of the trip. Approximately 210,000 Indonesian pilgrims travelled to Saudi Arabia in 2007. 
leverage over the local business community. In Pangkep district, for example, Syafruddin Nur, who won the regent election in 2005, distributed leaflets during his campaign in which he promised to issue a regulation that created incentives for the Imams...[These incentives would] be derived from contributions [infaq payments] amounting to 1 percent from every company that [was] to realise a government project [in Pangkep district]' (Syafruddin Nur, 2005). ${ }^{18}$

To provide a final example, in Makassar city, the shari'a by-law on zakat rules that the government zakat collection body, BAZ, has the authority to collect zakat from both private and state-owned enterprises. The zakat collection body was even given the authority to extract zakat from small vendors at local markets (Peraturan Daerah Kota Makassar No 5/Tahun 2006, Bab 8, Pasal 15, Ayat 1a-c, 2a-c). Based on this bylaw, the city government currently targets 73 nightclubs [THM - Tempat Hiburan Malam]. These karaoke bars, massage parlours and clubs are now obliged to pay $2.5 \%$ of their revenues to the government zakat collection body, BAZ (Fajar, 5 July 2007, online). H.M. Ruslan, the head of the 'Special Committee on the Planning of the Zakat by-law' [Pansus Ranperda Tentang Zakat DPRD Sulsel] of the provincial parliament, announced in July 2007 that the scope of the zakat by-law would soon be extended to include 'all companies in South Sulawesi, even those that have slipped through the [current] by-law...' (Fajar, 5 July 2007, online). ${ }^{19}$

\section{Increased local government revenues through shari'a by-laws}

Shari'a-inspired by-laws on zakat collection of the type described above greatly increased the revenues at the disposal of regents. Again, Bulukumba regency is an illustrative case. In 2001, the Bulukumba government employed 8,053 bureaucrats, falling into the categories listed in Table 2 (Badan Pusat Statistik Sulawesi Selatan, 2001, p 39). Against the backdrop of the obligatory infaq and sadaqah payments for state officials listed in Table 1, this yields around US\$34,000 per year just from infaq and sadaqah payments from state personnel in the four income brackets listed. To these revenues are added the money derived from the by-law requiring every bureaucrat in Bulukumba district

18 'Memberikan...insentif bagi Imam Masjid yang diperoleh dari infaq sebesar 1 persen setiap pengusaha yang melaksanakan proyek pemerintah' (Syafruddin Nur, 2005).

19 '...tapi seluruh perusahaan yang ada di Sulsel pun tak luput dari perda...' (Fajar, 5 July 2007, online). 
Table 2. Number of government civil servants, by rank.

\section{Bureaucratic rank}

\begin{tabular}{lcc} 
Bulukumba district & $\begin{array}{c}\text { City of Makassar } \\
\text { (year 2001) }\end{array}$ \\
Class I & 509 & 109 \\
Class II & 3,147 & 1,366 \\
Class III & 4,070 & 8,517 \\
Class IV & 327 & 3,769 \\
Government official & na & na \\
TPejabat Negara] & & 13,761 \\
Total & 8,053 & \\
\hline
\end{tabular}

Sources: Badan Pusat Statistik Sulawesi Selatan, 2001, p 39; Bagian Kepegawaian Kota Makassar, 2007.

to pay $2.5 \%$ of his or her salary each month to the government-run zakat collection body. This latter type of by-law has to be put in the context of the national tax law.

In 2003, the Director General of Tax in Jakarta had issued a decree to amend Law on Income Tax No 17/2000, ruling that zakat payments of up to $2.5 \%$ could be subtracted from a person's gross income (No KEP-163/PJ/2003, Article 1, Sections 1 and 3). ${ }^{20}$ Against this backdrop, the by-laws issued by the district government in Bulukumba or the city government of Makassar, which required every bureaucrat to pay $2.5 \%$ of his or her monthly income to zakat, did not create new revenues as such. Bureaucrats in Bulukumba or Makassar can simply deduct the zakat they are obliged to pay each month from their national tax payments. In short, both the regent in Bulukumba and the mayor of Makassar used shari'a by-laws to channel tax money into the local government zakat collection body, BAZ, at the expense of the tax revenues from their respective jurisdictions.

Overall, such shari'a by-laws have greatly enlarged zakat revenues

20 While the aforementioned Law on Zakat Management No 38/1999 stated that zakat given to BAZ or LAZ could be deducted from a taxpayer's income, zakat cannot be found on the list of deductions in the Law on Income Tax No 17/2000. On the contrary, it ruled that zakat collected by BAZ and LAZ could not be deducted from taxable income. This discrepancy led the Director General of Tax to issue a tax decision in 2003, stating that zakat up to $2.5 \%$ paid to BAZ and LAZ could be subtracted from gross income (No KEP-163/PJ/2003, Article 1, Sections 1 and 3). However, this deduction applies to income tax only. Zakat on capital gains is still not tax-deductible. See also Alfitri's (2006, pp 64-65) elaborations on the inconsistencies in the Law on Zakat Management No 38/1999. 
in many districts of South Sulawesi. ${ }^{21}$ The Preparatory Committee for the Implementation of Islamic Law, a group lobbying for the implementation of shari' a by-laws in South Sulawesi already mentioned above, claims that in Bulukumba district, revenues from zakat-mal alone rose from US\$900,000 (IDR9 billion) before the by-law to US\$8-9 million (IDR80-90 billion) after the by-law on zakat was adopted (KPPSI, 2005, p 178). The same amount was mentioned during an interview by Patabai Pabokori, the regent during whose tenure the new zakat system was adopted (Patabai Pabokori, 2006).

In the city of Makassar, a study conducted by the municipality government in July 2007 concluded that infaq and sadaqah payments alone from the more than 13,000 bureaucrats in the city administration would bring in at least US\$15,600 (IDR156 million) per year for the coffers of the zakat collection body of the municipality government (Fajar, 4 October 2007, online). However, this seems to be a gross understatement. Calculations based on official government statistics (summarized in Tables 1 and 2) show that the city government in Makassar earned no less than US\$101,270 per year through infaq and sadaqah payments alone, deducted directly from city bureaucrats' salaries. ${ }^{22}$

Furthermore, the study stated that, so far, the by-law on additional mandatory zakat payments had been imposed on only $50 \%$ of the city's bureaucrats. Nevertheless, zakat collection had already raised

21 Regents in South Sulawesi also used shari'a by-laws to control economic resources in other ways. In several districts, regents adopted by-laws on the consumption of alcohol. These 'hard liquor by-laws' [perda miras-minuman keras] often work to the advantage of the regent and his affiliates. In various districts, such by-laws did not forbid the consumption of alcohol entirely, but only regulated it. Often this created a monopoly on the sale of hard liquor by people close to the regent. Some members of the Preparatory Committee for the Implementation of Islamic Law, the shari' a lobbying group mentioned above, themselves pointed out the rather mundane rationale of regents for implementing shari' a by-laws on alcohol consumption and distribution. Sawati Lambe, Deputy Head of the Preparatory Committee for the Implementation of Islamic Law in the city of Parepare, said during a debate on a hard liquor by-law in the local parliament: 'If [the selling of alcohol] is only regulated [but not completely forbidden], this is just abusing [the regulation]. This regulation on liquor is just going to enrich certain people' ['Kalau hanya mengatur, itu sama halnya main-main saja. Pengaturan miras hanya akan memperkaya orang-orang tertentu'] (Tribun Timur, 3 July 2006, p 30).

22 This number is derived by adding the total infaq and sadaqah payments per bureaucrat for all four ranks. The US\$15,600 infaq and sadaqah revenues per year reported in the government's study were underreporting the amount of money netted because the study simply assumed that the IDR1,000 a month payment would apply to all four bureaucratic ranks. Table 1 shows, however, that this is not the case. According to the shari' a by-law on zakat collection in Makassar, bureaucratic ranks pay different amounts of infaq and sadaqah per month. 
US $\$ 360,000$ (IDR3.6 billion) per year, the study concluded (Fajar, 4 October 2007, online). In an interview in October 2007, the Mayor of Makassar, H. Ilham Arief Sirajuddin, stated that he expected zakat revenues from the bureaucrats in his administration and the broader population to rise to US\$150,000 per month in the future (Ilham Arief Sirajuddin, 2007).

Against this backdrop, it is no surprise that Azwar Hasan, spokesman for the Preparatory Committee for the Implementation of Islamic Law, stated with a big grin during an interview that '[o]verall, local governments are [implementing] zakat by-laws quite enthusiastically because they profit from them' (Azwar Hasan, 2006).

\section{The distribution of zakat revenues generated through local shari'a by-laws}

The great discretionary power over the zakat collection process, as well as the domination regents enjoyed over government zakat collection bodies, ${ }^{23}$ allowed the regents in several districts to redistribute revenues obtained through shari'a by-laws both before and after local elections in ways that consolidated their power. Most striking in this respect is the district of Barru in South Sulawesi, where H. Andi Muhammad Rum and his deputy H. Kamrir Daeng Mallongi were reelected in 2005 with $52 \%$ of the votes, the second best result in the entire province. ${ }^{24}$ As Kamrir Daeng Mallongi, the Deputy Regent, explained, zakat revenues were used by his government both before and after the elections,

'to improve the religiosity of the district. In Barru, we already know that 99 percent of [the inhabitants] follow Islam. Against this backdrop, what can we do, we wondered, for the religious life [in the district]? We saw that people who work for society through religious activities, such as Qur'an reading teachers [or] Imams in the mosques, sometimes didn't get enough attention from previous governments. I mean, they really work in such jobs because they hope eventually to

23 The shari' a by-law on zakat of Makassar city, for example, rules that the auditor who overseas the zakat distribution is to be appointed by the mayor of the city (Peraturan Daerah Kota Makassar No 5/Tahun 2006, Bab 13, Pasal 26, Ayat 2).

24 Only one regent, Syafruddin Nur, achieved a better result. Nur collected $58 \%$ of the votes in Pangkep district. See Buehler and Tan (2007) for the complete election results for the first direct elections of regents in South Sulawesi province in 2005. 
be paid by God. But we know that they want to eat, they have children, they have families they want to feed...Therefore, we thought what is needed is an incentive by the government...so that they can truly focus on their activities...[T]his has been well appreciated by the population. After this analysis, we drew up a budget [menganggarkan] for Qur'an reading teachers [and] Imams in the villages. Their responsibilities lie not only with activities concerning their mosques but they also have religious obligations concerning the well-being of the people. They have to [read from the Qur'an] at people's funerals and the like. For sure, if they don't get support, they cannot focus on such activities. They want to eat too!...That's why we came up with an incentive for such people... so that they can see we value them as leaders. We spoke to religious leaders [kiyai] [and showed them] we, [the government] have potential. We have money not only from the local budget but also from within the larger population. We can make the wider population contribute via zakat. That's why we adopted a by-law on zakat. We adopted a shari'a bylaw on zakat...so that we can do justice to the truly charismatic local leaders [tokoh masyarakat] [who] have an extraordinary understanding of religion. It was [such local notables] who looked for people to support their leadership [kepengurusan]. This motivated us to collect zakat. And the results have been extraordinary! We have managed to collect almost USD 100,000 [IDR1 billion] in zakat revenues.' (Kamrir Daeng Mallongi, 2006).

As becomes clear, the regent and his deputy were distributing money to religious figures of the type described above, fully aware of the important role such religious notables play as vote brokers. The money came to a large degree from zakat revenues raised by the local government and channelled into the government zakat collection body, BAZ. This was confirmed not only by Kamrir Daeng Mallongi quoted above, but also by Muhammad Rum, the regent himself, in an interview (Muhammad Rum, 2006).

After being re-elected as head of Barru district in 2005, Muhammad Rum consolidated the scheme described above that distributed money to religious notables. This is shown by various records collected at the district treasury in Barru district. From January until June 2006, for example, the regent of Barru district paid 750 Qur'an reading teachers US\$7 (IDR70,000) each month, 368 mosque preachers and mosque personnel US\$7.50 (IDR75,000) each month, while 193 mosque leaders 
and their assistants received, due to their higher social status and thus their higher value as vote brokers, US\$10 (IDR 100,000) each month (Bendaharawan Kabupaten Barru, 2006a-c). In short, a staggering 1,311 religious notables, previously working on a voluntary basis, now received a monthly cash donation from the regent. They all had to show up personally at the regents's office to receive the money. Their signatures, or in the case of the illiterate ones, their fingerprints, on the documents quoted above, show that every single one of them took their money each month, as presented in Figure 1.

A comparison of the recipients' geographical distribution (Table 3) and the election figures (Table 4) from the direct elections in 2005, won by Muhammad Rum, shows an interesting pattern. Those subdistricts where the margins between Rum's election result and that of his main competitor Anwar Aska were smallest, namely Soppeng Riaja and Balusu subdistricts, were always amongst those subdistricts where the smallest number of religious notables received a monthly cash injection. ${ }^{25}$ In other words, the incumbent and his deputy consolidated their turf by distributing money to religious notables in 'their' subdistricts, while in subdistricts that were strongholds of their rival, a smaller number of power brokers received money. ${ }^{26}$

Regents in other districts of South Sulawesi invented similar strategies. The political and economic rationales for implementing shari'a

25 These are the subdistricts highlighted grey in Table 3. The subdistricts of Soppeng Riaja and Balusu have only around half the electorate compared with the larger subdistricts, as shown in Table 4 . One could thus point out that confounding elements such as district size and electorate figures have not been neutralized in the comparison above. Indeed, the aformentioned comparison would be more accurate if the level of support for religious teachers could have been calculated on a per capita basis for each subdistrict. However, despite repeated visits to the Department of Religion in Barru district, it was not possible to obtain total numbers of religious figures in the district. In fact, the Department of Religion in Barru referred to the District Treasury's documents used in Table 3 as the comprehensive lists of imams in Barru district. Furthermore, the fact that in Pujananting, the smallest subdistrict, a greater number of religious figures received money than in the larger subdistricts of Soppeng Riaja and Balusu, is evidence that the distribution of these zakat revenues has become politicized in Barru regency. Recent documents gathered on a research trip in December 2007 support the aforementioned claim further. The general zakatrevenue distribution scheme was expanded throughout 2007, and an even greater number of religious notables received zakat revenues from the regent. The number of Qur'an reading teachers in Balusu subdistrict who received zakat revenues, however, dropped compared with the year 2006 quoted above.

26 Andi Anwar Aksa, the main competitor of the government head Muhammad Rum, is actually the latter's cousin. The family feud between them shapes political dynamics in Barru district. 


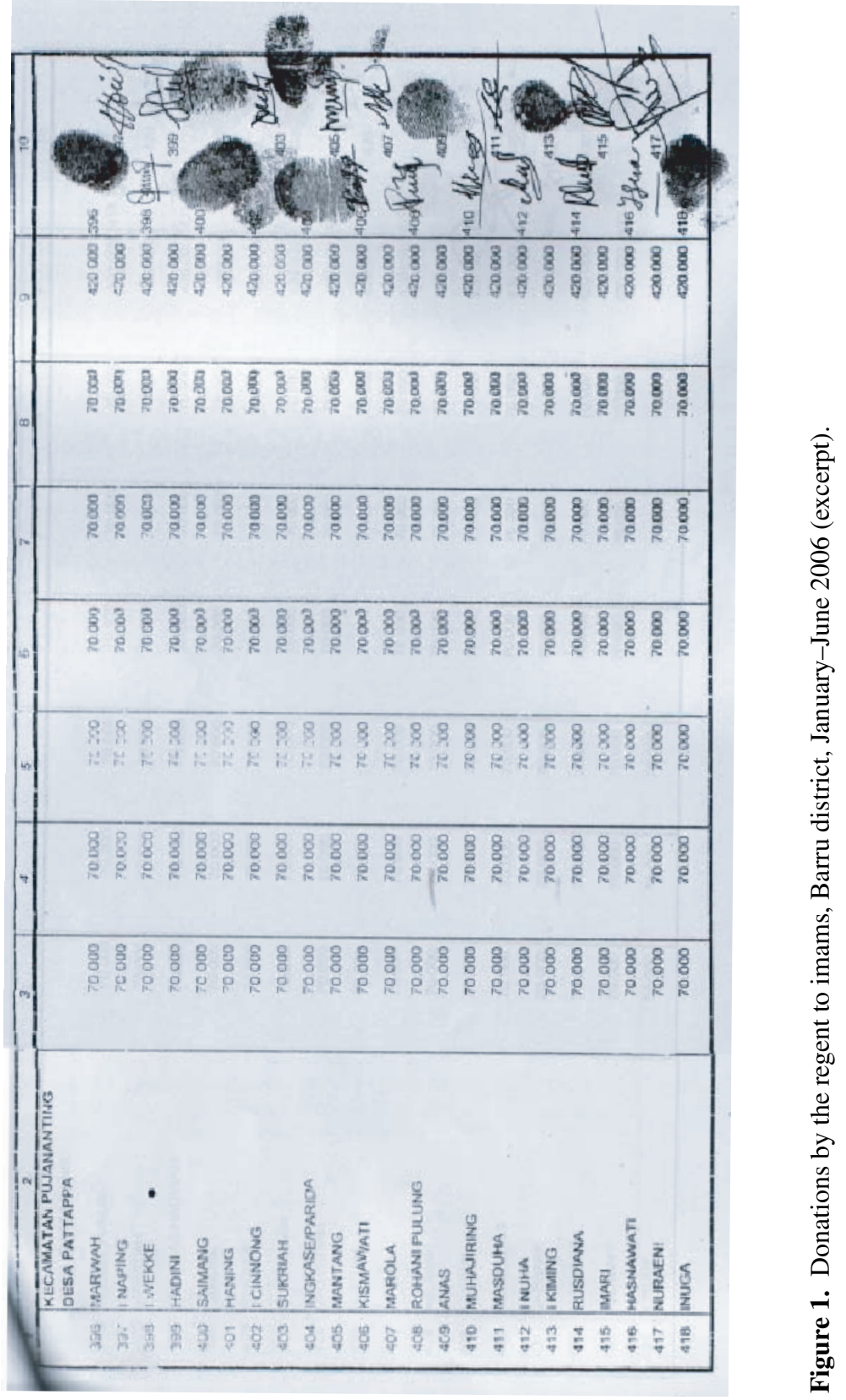


Table 3. Donations by the local government in Barru district, January-June 2006, by profession and subdistrict.

Mosque leaders and assistants [Imam Masjid dan Pembantu PPN-Imam Desa] Subdistrict Number of recipients

Total amount of money spent

$\begin{array}{lrr}\text { Balusu } & 22 & \text { IDR } 13,200,000 \\ \text { Barru } & 34 & \text { IDR20,400,000 } \\ \text { Mallusetasi } & 15 & \text { IDR } 9,000,000 \\ \text { Pujananting } & 30 & \text { IDR } 18,000,000 \\ \text { Soppeng Riaja } & 22 & \text { IDR } 13,200,000 \\ \text { Tanete Riaja } & 31 & \text { IDR } 18,600,000 \\ \text { Tanete Rilau } & 39 & \text { IDR23,400,000 } \\ \text { Total } & 193 & \text { IDR } 115,800,000\end{array}$

Qur'an Reading Teachers [Guru Mengaji]

\section{Subdistrict}

$\begin{array}{lr}\text { Balusu } & 71 \\ \text { Barru } & 157 \\ \text { Mallusetasi } & 101 \\ \text { Pujananting } & 100 \\ \text { Soppeng Riaja } & 83 \\ \text { Tanete Riaja } & 107 \\ \text { Tanete Rilau } & 131 \\ \text { Total } & 750\end{array}$

Total amount of money spent

IDR29,820,000
IDR65,940,000
IDR42,420,000
IDR42,000,000
IDR34,860,000
IDR44,940,000
IDR55,020,000
IDR315,000,000

IDR29,820,000

IDR65,940,000

IDR42,420,000

IDR42,000,000

IDR34,860,000

IDR55,020,000

IDR315,000,000

Mosque preachers and mosque personnel [Khatib/Bilal dan Pelayan Masjid]

\begin{tabular}{lcc} 
Subdistrict & Number of recipients & Total amount of money spent \\
Balusu & 28 & IDR12,600,000 \\
Barru & 77 & IDR34,650,000 \\
Mallusetasi & 52 & IDR23,400,000 \\
Pujananting & 40 & IDR $18,000,000$ \\
Soppeng Riaja & 47 & IDR2 $1,150,000$ \\
Tanete Riaja & 58 & IDR26, 100,000 \\
Tanete Rilau & 66 & IDR29,700,000 \\
Total & 368 & IDR165,600,000 \\
\hline
\end{tabular}

Source: Bendaharawan Kabupaten Barru, 2006a-2006c.

by-laws regulating the collection and distribution of zakat were quite obvious in Enrekang district, where the regent La Tinro La Tunrung is facing direct elections in 2008. He has been expanding his local network at the subdistrict level via religious notables. On 17 June 2006, for example, La Tinro La Tunrung personally distributed no less than US $\$ 39,750$ (IDR97.5 million) in a single day to 53 imams, summoned to his office from all the subdistricts in his district. ${ }^{27}$ A local newspaper published a picture showing La Tinro La Tunrung handing out wads of

27 Each imam received US\$750 (IDR7.5 million) to improve the appearance of his mosque. 


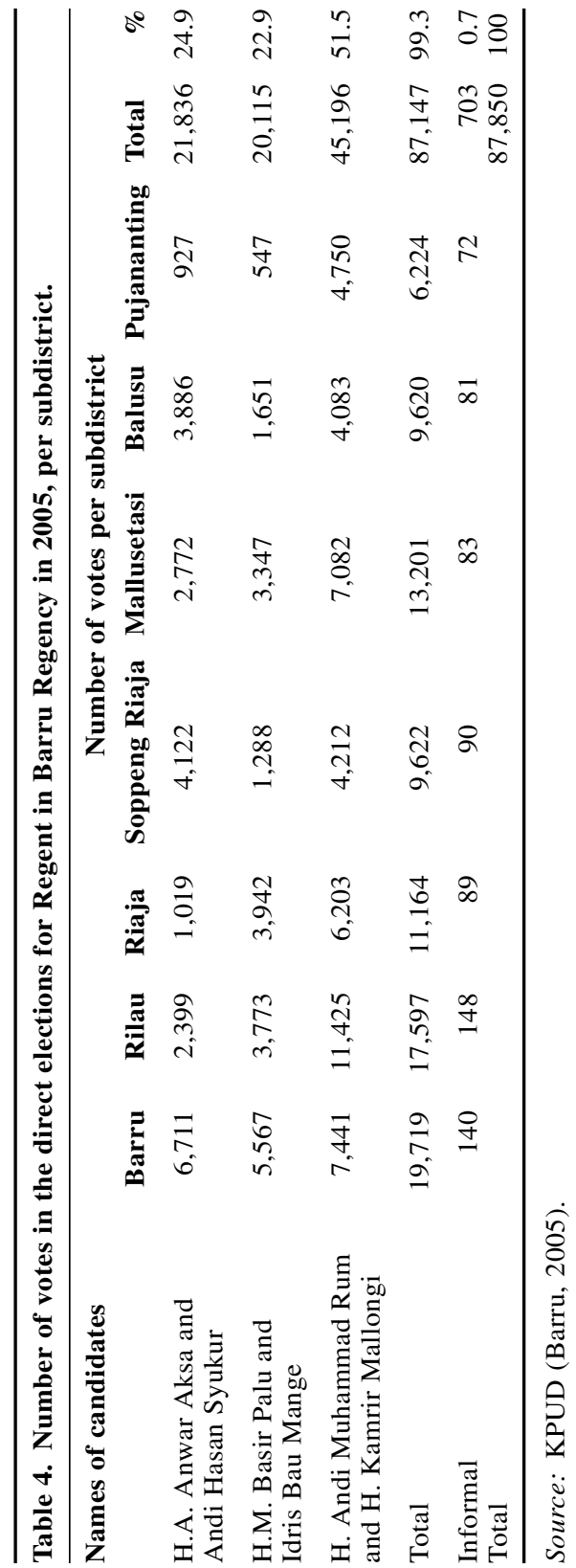


cash to the religious notables lined up (Fajar, 19 June 2006, p 32). Just for those who thought otherwise, La Tinro La Tunrung dictated into the journalists' microphones: 'This has nothing to do with politics!' (Fajar, 19 June 2006, p 32). ${ }^{28}$

In Bulukumba too, Patabai Pabokori, the former regent already mentioned above, used money obtained through zakat by-laws to establish and nurture networks at the subdistrict level. Without distributing money one cannot win direct elections, Patabai Pabokori stated in an interview. 'These days, the people are already smart. They know that once you become regent, you are going to have a lot of money' (Patabai Pabokori, 2006). Again, photographs show Patabai Pabokori distributing money to religious notables in public (Patabai Pabokori, 2005, p 133). ${ }^{29}$

Patabai Pabokori also established another scheme to penetrate subdistricts. He established a programme in which certain villages in the subdistricts were chosen by the regent to become 'Muslim villages' [Desa Muslim] (Patabai Pabokori, 2005, pp 74-75). These villages were assigned the task of being as 'Islamic' as possible, resulting in women being urged to wear headscarves, inhabitants being obliged to deposit their money in shari' a banks, street and government office names being written in Arabic, and local government buildings greeting visitors with signs reading 'We are sorry! We do not serve customers not wearing a jilbab' (Mulia, 2006). ${ }^{30}$ By December 2007, 12 'Desa Muslim' had been established in Bulukumba district. As God blesses those who follow him, villages that have been selected by the regent to become 'Muslim villages' receive additional budget funds from the district government, mainly derived from zakat (Mulia, 2006).

Regents also used zakat funds obtained through shari'a by-laws to support semi-criminal militias. In South Sulawesi, Laskar Jundullah, the

28 'Ini tidak ada hubungannya dengan politik' (Fajar, 19 June 2006, p 32).

29 The mosque-building frenzy in Bulukumba during Patabai Pabokori's tenure led to great frustrations within the population, especially among bureaucrats in Bulukumba district, who paid for it all through their mandatory infaq, sadaqah and zakat contributions. For example, a local newspaper in South Sulawesi to which people can anonymously send mobile phone text messages, which are then published the next day, received various such messages from bureaucrats in Bulukumba district. One complained that if his salary was cut each month for infaq, sadaqah and zakat payments, which were then allegedly used for mosque projects run by the regent, he would at least expect these mosques to be really built. So far, the sender informed the newspaper, not much had happened in that respect (Tribun Timur, 28 July 2006, p 17). Local protests against shari' a by-laws of the kind mentioned above have been largely absent. This might have to do with the fact that the by-laws on zakat, for example, have mainly targeted the bureaucracy and not (yet) the broader population. 
paramilitary wing of the Preparatory Committee for the Implementation of Islamic Law, drawing on local gangs and youth groups, ${ }^{31}$ has become a kind of informal shari' a police force in many districts. Revenues collected by regents through shari'a by-laws were used to support this organization. As Patabai Pabokori, the former regent of Bulukumba, stated: 'The money from zakat [collection] is for the poor. There are many thugs among poor people. If you give them money, then they keep quiet' (Patabai Pabokori, 2006). Applying some interesting logic, Patabai Pabokori further stated that the crime levels in Bulukumba regency had dropped since the implementation of shari'a by-laws, because petty criminals and thugs were now paid by the district government to be part of Laskar Jundullah, patrolling the streets in his district and supervising the implementation of shari'a (Patabai Pabokori, 2006). ${ }^{32}$ In several districts, Laskar Jundullah members have also served as election witnesses during the direct elections of regents and have come to play important roles in steamrolling tactics and intimidation, both before and after elections.

Finally, as mentioned above, several by-laws in South Sulawesi gave great discretionary power to the regent to select private zakat collection bodies (LAZ). This further strengthened the role of the regent. Given the fact that zakat collection in South Sulawesi, and Indonesia in general, is often conducted by private zakat collection bodies affiliated with institutions or pesantren that also carry political weight in local politics, such as Muhammadiyah, Nahdlatul Ulama (NU) or locally influential pesantren such as DDI Mangkoso or Hidayatullah in the case of South Sulawesi province, shari'a by-laws that allow the regent to approve or reject private zakat collection bodies provide the regent with a formidable tool to reward political allies and punish foes. ${ }^{33}$

31 'Many of its [Laskar Jundullah] members have backgrounds in local gangs and it is a feared presence in South Sulawesi, where it regularly intimidates parliamentarians, officials and the media into supporting its moves to implement shariah [sic!]' (Fealy, 2002, p 10).

32 The symbiosis between such pseudo-religious organizations and criminal activities is nothing new and is not bound to the Indonesian context. Bayart wrote in his study of the criminalization of the state in Africa: 'In the most extreme cases, crime actually flourishes in the bosom of religion: bandits can be assiduous in undertaking pious works (thus giving rise to the notion that they can be "social") and in the Ottoman Empire or nineteenth-century India outlaws were commonly graduates of Koranic schools or former members of ascetic brotherhoods' (Bayart, 1999, p 36).

33 Shari'a by-laws other than the ones on zakat collection covered in this article seem to serve similar ends: namely to increase revenues and channel the money in directions that were useful to win elections, either by nurturing networks at the subdistrict level or by simply paying campaign expenses. In Barru district, for example, a shari'ainspired by-law on alcohol consumption, of the kind already mentioned in a footnote 


\section{Changing patterns of power accumulation and political corruption}

As shown in the paragraphs above, the implementation of shari'a bylaws in various districts of South Sulawesi allowed regents to raise revenues in their districts through the collection of zakat. ${ }^{34}$ These new revenues were then used to establish and nurture networks of power brokers at the district and subdistrict level. Seen in this light, shari'a by-laws on zakat constitute a predatory tax, whose implementation is driven by local political elites and which serves their political interests. In other words, official government programmes camouflaged as contributions to religious notables were actually used to bribe local power holders.

The aforementioned developments have to be situated in the context of institutional reforms adopted after the demise of the New Order in 1998. One important new regulation concerns the election of regents. These were put on a new legal basis on 14 October 2004 with the implementation of the new Regional Governance Law No 32/2004. ${ }^{35}$ It ruled that regents were to be elected directly by the people and that candidates had to be nominated by a party or a coalition of parties that had gained $15 \%$ of the votes in past elections, or occupied $15 \%$ of the seats in the local parliament. ${ }^{36}$ The first direct elections under the new regulations were conducted in June 2005 in 226 districts across the archipelago.

As shown elsewhere, the new institutional framework for the election of regents both increased the importance of personal networks of power brokers at the local level (Buehler, 2007) and forced up the costs of competing in such elections (Buehler and Tan, 2007). 'The [electorate]

above, does not completely forbid the consumption of alcohol in the district; it merely regulates it. It ruled that in the entire district, only one hotel was allowed to sell alcohol. The hotel is owned by the head of the South Sulawesi Hotel Association (PHRI - Perhimpunan Hotel dan Restoran Indonesia), a member of the pro-government political party Golkar and one of the financiers of the district head's election campaign.

34 They also raised their revenues through the establishment of alcohol monopolies or by imposing new regulations on local businesses, as briefly mentioned above.

35 Regional Governance Law No 32/2004 replaced the previous law on Regional Autonomy No 22/1999.

36 Regional Governance Law No 32/2004, Article 56, Paragraph 2, Article 59, Paragraph 1 . On 23 July 2007, the Constitutional Court in Jakarta overruled this article in the autonomy law, allowing candidates to run without a party nomination in future local elections. On 28 April 2008, revised Regional Governance Law No 12/2008 was adopted, allowing independent candidates to stand in regent elections. 
has become for the regent what sugar is for an ant. The ant has to get close to the sugar...', as H. Kamrir Daeng Mallongi, the Deputy Head of Barru district aptly described the new relationship between local elites and the wider population after the introduction of direct elections (Kamrir Daeng Mallongi, 2006).

In other words, institutional reform in post-New Order Indonesia has created an environment that is highly receptive to political strategies that have been described as machine politics in other contexts, namely 'the purchase of votes with offers of public jobs and services...' (Erie, 1988, p 2). Shari' a by-laws on zakat that allow political elites to raise revenues and distribute them at their discretion have to be situated in this context.

Political elites must now establish linkages to the electorate, preferably to those constituencies that are crucial for a victory at the ballot box:

' $[\mathrm{I}] \mathrm{n}$ the case of clientelism, under conditions of democratic enfranchisement the major cost of constructing such linkages is that of building organizational hierarchies of exchange between electoral clients at the ground floor of the system, various levels of brokers organized in a pyramidal fashion, and patrons at the top. Politicians have to identify resources they can extract and offer to clients in exchange for contributions to their electoral efforts. Moreover, they must construct organizational devices and social networks of supervision that make direct individual or indirect group-based monitoring of political exchange relations viable.' (Kitschelt and Wilkinson, 2007, p 8)

These highly concentrated and focused exchanges of goods between political elites and certain groups within the electorate often raise other issues. There is always the risk of opportunistic defections. Either political elites who promised money or favours in exchange for votes do not live up to their pledge, or voters 'take the money and run', ie they do not vote for those politicians who gave them goods or money. Against this backdrop, political elites engaging in machine politics with parts of the electorate can only succeed if they have the means to monitor these exchanges, and if need be, impose the terms of their clientelistic bargain through various forms of organizational surveillance and enforcement structures.

Coercive and violent forms of punishment definitely occur during 
clientelistic exchanges and are generally not given enough attention in the study of such relationships (Sidel, 1999). However, such forms of enforcement are usually costly and political elites generally prefer lowercost methods of monitoring and enforcement. Hence group rather than individual monitoring techniques tend to be employed as well as public methods of monitoring, instead of networks of private informants. While the efficiency of monitoring groups is directly related to group cohesion, there are various options at hand for political elites also to monitor constituencies where group cohesion might be less distinct. One such method is constant interaction with a group or its leaders over time. Clientelistic exchanges then become an 'ongoing, iterative process in which the past behavior of...individuals, and communities present expectations of the obligations of patrons to clients and vice versa' (Kitschelt and Wilkinson, 2007, p 17). Continued interaction and exchange between patrons and clients over time - for example, at local celebrations - may eventually make such regular monitoring of voting unnecessary.

\section{Shari'a by-laws provide political elites with a tool to address new challenges}

In South Sulawesi province, regents adopted shari' a by-laws as a means to address challenges of the kind described above.

First, shari' a by-laws allow political elites to raise goods and money that can subsequently be distributed to certain constituencies. Most important in that respect are the by-laws on zakat that have already been adopted by roughly one-third of all the districts in the province. Such by-laws on alms have allowed regents to raise considerable amounts of money, often equalling several hundred thousand US\$ per year. Usually, such shari' a by-laws on zakat target the local bureaucracy, ie every bureaucrat is obliged to pay a certain amount of his or her salary to a government-controlled zakat collection body (BAZ), or they target specific businesses such as nightclubs and karaoke bars. In both cases, the collection of zakat is relatively straightforward and does not require much organizational effort. Monthly zakat payments are simply deducted from bureaucrats' salaries, while the semi-legal status of nightclubs and karaoke bars makes their owners vulnerable and thus less prone to resistance.

While shari'a by-laws on the collection of zakat are always very 
precise about who must pay such contributions, ${ }^{37}$ documents showing the distribution of such funds by district governments are either nonexistent or very vague in the rare cases where they actually exist. ${ }^{38}$ The 2006 annual report of the government-run zakat collection body in Barru district, for example, covers only two pages detailing the dispersion of US $\$ 88,442$ (IDR884,421,484). The report simply states that 770 'poor people' [Miskin], 72 converts [Muallaf] and 28 mosques [Mesjid] had been given some money (Laporan Pengurus BAZ Barru, 2006, p 2).

The dispersion of revenues raised through zakat, then, is to a large degree at the discretion of the regent. Providing benefits for certain subsets of citizens while imposing costs on other subsets, shari'a bylaws on zakat are thus a perfect example of the creation of goods popular with politicians engaging in clientelistic politics.

In various districts, revenues raised through shari'a by-laws have been expended on locally influential religious notables and pesantren with the aim of establishing tightly knit networks of imams and Qur'an reading teachers. It is these religious notables who serve as power brokers between the political elite and the broader population in the context of elections.

In fact, even 'symbolic' shari'a by-laws have acquired political meaning in the context of institutional change and the new challenges regents face. By establishing 'Muslim subdistricts' or 'Muslim villages', areas in which shari'a law is extended to all aspects of life, regents in several districts of the province have used shari'a by-laws to extend their control even further to the subdistrict level. Both the material incentives they have offered, and the increased attention that power brokers and the broader population receive from local political elites in such areas, are aimed at establishing social networks of supervision, making direct individual or indirect group-based monitoring of political exchange relations in the context of competition over power viable.

Shari'a by-laws have also been used to streamline and co-opt certain networks, most obviously those that arise from within the state apparatus. Various regents have adopted shari'a by-laws making vaguely

37 The shari'a by-law on zakat in Maros, for example, shows a very elaborate table, stretching over four pages, identifying the various groups that have to pay alms (Peraturan Daerah Maros No 17/2005, Pasal 17).

38 From the 17 districts in South Sulawesi that have adopted shari'a by-laws on zakat, it was possible to obtain documents on the dispersion of zakat funds from only two districts, Barru and Maros. 
defined 'Qur'an reading capability' a criterion for becoming a member of the district bureaucracy, or for promotions. This allows the regent to streamline the bureaucratic apparatus drastically in the district under his control, while also increasing the power of local political elites occupying state positions. It is such lower rungs of the bureaucracy that have become increasingly important in establishing linkages to the electorate following the introduction of direct elections for regents. ${ }^{39}$

Also, shari'a by-laws on improving the Qur'an reading skills of the local population provide political elites with a tool to tap into various networks forming the electorate. Scholars working on the phenomenon of Qur'anic recitation practice in Indonesia have pointed out the community-building effects of such exercises:

'Historical traditions of the public recitation of the Qur'an in the Indonesian archipelago are associated with the religious patronage of ruling elites as well as with widespread Sufi-oriented practices of piety...Sufi networks of teaching, practice, and performance complemented and overlapped the formation of other institutions and systems of education in the Muslim archipelago.' (Gade, 2004, p 31)

In other words, it is such networks of mosques, pesantren and study groups created around different styles of Qur'an recitation, ${ }^{40}$ which form a fabric that supplements official state institutions and the networks that arise from the state. Influential Qur' an memorization teachers create a heritage that includes '...families and networks known for

39 An example of the power that lower bureaucrats have acquired in the context of decentralization and direct elections and the role as power brokers they have come to play is provided by the Health Insurance for the Poor [Askeskin-Assuransi Kesehatan Miskin] programme, which was adopted by the Indonesian government in 2005 . The insurance scheme was designed to increase health coverage of poor people by removing the financial barriers to access to health services. One major flaw in the very laudable programme was that it placed the responsibility of selecting beneficiaries with local governments. Concretely, poor people who wanted to gain access to the scheme needed a letter from the village head [lurah], who is appointed by the regent. Unsurprisingly, in order to win popular favour, local governments greatly expanded the membership of the Health Insurance for the Poor programme in gross disregard of the quotas approved by central government, on whom the entire costs of the scheme fell. Only two years after its establishment, the scheme was already in deep financial crisis (Wheeler, 2007, p 15).

40 Most commonly featured in Indonesia is the mujawwad style of Qur'an recitation called tilawah in the Indonesian language. In South Sulawesi, more traditional styles such as murattal are still practised (Gade, 2004, pp 34-35). They are often referred to by locals as 'weepy songs' [lagu nangis]. On the history of Qur' an recitation in Makassar, see Gade, 2004, pp 31, 269. 
memorization...' (Gade, 2004, p 32). More institutionalized Qur'an recitation groups such as Majelis Ta'lim are another example of tightly knit networks that can be found not only in South Sulawesi province, but in Indonesia in general. It is against this backdrop that the system of Qur'anic recitation has been described as a 'machinery of social structure' (Gade, 2004, p 48).

Adopting shari'a by-laws on Qur'an recitation skills allows regents not only to enhance such networks, but also to use them to structure the electorate and mobilize it at election times. The massive amounts of money regents spend on such Qur'an recitation exercises provide ample evidence of the importance local political elites attribute to networks attached to such practices. ${ }^{41}$

Furthermore, it is the same shari'a by-laws that establish access to networks of the kind mentioned above that also allow local political elites to minimize the risk of opportunistic defections. Pursuing machine politics, in certain districts of South Sulawesi regents have used revenues raised through shari'a by-laws to establish a semi-official shari' a police, consisting of barely disguised petty criminals and hoodlums, who have now come to play a role in organizational surveillance and enforcement structures in the context of local elections.

Monitoring usually works in more subtle ways, however. Politicians and constituents gain confidence in the viability of their clientelistic relationship by iteration, as mentioned above. In other words, continued interaction and exchange over time induce expectations of reciprocity and may make constant monitoring of voting unnecessary. Shari'a bylaws allow regents not only to institutionalize the exchange of cash and goods, but also to enforce such social interaction. Shari'a by-laws on the establishment of 'Muslim villages and subdistricts' in Maros district rule that these designated areas receive regular cash transfers from the district government. Likewise, the scheme established in Barru regency required more than 1,000 imams to turn up every month at the district government office to receive a cash donation funded through a shari'a by-law on zakat. Finally, sponsoring Qur'an recitation meetings, which are held weekly if not daily, serves as a constant reminder

41 In 2006, La Tinro La Tunrung, the regent of Enrekang district, spent US\$130,000 (IDR1.3 billion) from the district budget on Qur'an reading training. The money was mainly handed out to imams and mosque personnel. M. Darwis, the Head of Enrekang's Department of Religion, stated that the US\$130,000 was a necessary investment with regard to the Qur' an reading competition between districts held in the province that year (Fajar, 19 June 2006, p 32). 
to large parts of the electorate as to whom they should be showing loyalty on election day.

What becomes evident is that the rise of shari'a by-laws indicates broader changes in the patterns of power accumulation and political corruption in Indonesian local politics.

\section{Patterns of power accumulation and political corruption during the New Order}

During the New Order, regents and governors were appointed by central government based on lists drawn up by local assemblies. These 'elections' were certainly rife with practices in which money and favours changed hands. Interest groups and individuals lobbied regional assembly members, 'often at the instigation of potential candidates' (Malley, 1999, p 162). This happened mainly in the short time between the incumbent handing in his letter of resignation and the day the local parliament was expected to submit its list of prospective candidates to higher-level bureaucrats, who then decided who would become regent. Since Golkar was almost always the majority party in the local assemblies, most of the lobbying and bribing actually took place within the party itself (Malley, 1999, p 62).

The most immediately obvious difference in the situation faced by local politicians since 1998 was that the exchange of money and favours was no longer oriented upwards, as during the New Order. In the past, appointments were decided by how much money or how many favours were given to decision makers higher up the pecking order. ${ }^{42}$ In South Sulawesi province, for example, Colonel Ahmad Lamo, who became governor in 1966, was rather unpopular with the local population, but greatly liked by central government, especially after the provincial Golkar party machine under Lamo's guidance reaped an impressive number of votes in the first legislative elections under the New Order regime in $1971 .{ }^{43}$ It was against this backdrop that '[a]11 political groups in the region realized that whether Lamo was reappointed or not depended entirely on the central government' (Amal, 1992, p 169). A national newspaper cynically commented that the central

42 Even during the New Order, local power holders needed to distribute favours and money to the local population to gain support. However, controlling constituencies was relatively unimportant to remain in power, in contrast to good relationships with higher-level bureaucrats and politicians.

43 In the 1971 legislative elections, $78.2 \%$ of the electorate voted for Golkar (Amal, 1992, p 166). 
government's decision would largely depend on how much 'precious metal' Lamo would pass on to top government officials in Jakarta (Tempo, 19 February 1972). ${ }^{44}$ In short, bills were settled long before the actual 'election' of the regent, and they involved payments to a strictly limited number of people. Furthermore, political corruption occurred in more or less predetermined channels dictated by the centralized power structures of the New Order regime. All this changed dramatically with the democratic decentralization that followed the post-1998 reforms.

\section{Conclusion}

The conditions for power accumulation in Indonesian politics have changed profoundly since the adoption of various institutional reforms adopted after the demise of the New Order in 1998. In particular, local political elites are facing entirely new dynamics. With the introduction of direct elections for regents, candidates were confronted, almost overnight, with the task of 'working' several hundred thousand voters, while during the New Order bribing a few people had been sufficient to get a candidate into office. This not only created financial challenges of an entirely new scale, but the 'business of governance' in Indonesian districts also became much more unpredictable and less predetermined.

Most immediately important, the democratization of political institutions has resulted in a democratization of political corruption. Corruption patterns in Indonesian districts increasingly resemble what Scott has termed 'market corruption', ie a system within which the exchange of money or favours has become an impersonal process and in which influence is accorded to those who can pay the most, regardless of who they are. While there is no full-blown market corruption in South Sulawesi, and while personal relationships between candidates and the electorate remain important, the fact that politics is increasingly decided by money and not so much by traditional loyalties, provides ample evidence for a democratization and 'marketization' of political corruption in the province. The deregulation of political corruption currently under way in Indonesian local politics, then, has forced local political elites to look for new strategies to accumulate

44 '...kebidjaksanaan Pusat itu mungkin akan sangat tergantung pada logam mulia jang alamat pengirimnja...' (Tempo, 19 February 1972, p 47). 
and disperse power. ${ }^{45}$ The implementation of shari'a by-laws is one such strategy.

The attraction of shari'a by-laws for regents has to be seen against this backdrop of widening uncertainties and insecurities in the terms of contestation among elites competing for local posts. The religious context within which revenues are raised through shari'a by-laws not only veils bribery and electoral corruption with certain 'social cosmetics', but more importantly, such by-laws produce a kind of glue that increases the degree of predictability. These by-laws have turned out to be a useful means of addressing many of the challenges faced by local political elites, such as raising revenues for political ends, establishing linkages to the electorate, and monitoring constituencies. Shari'a bylaws, in other words, are an attempt by local political elites to re-regulate political corruption practices that emerged in the context of institutional change.

The growing attraction of shari'a-inspired by-laws, and the change in political corruption for which they stand, also confirm the old finding that political resources are made more or less valuable by the nature of a political system (Scott, 1972, p 88). While in the authoritarian setting of the New Order, control over the Golkar party branch or a key military unit was a viable source for demanding favours, in post-New Order Indonesia, control over a bloc of votes has become a resource that can be traded against cash. The changing value of political resources, then, has resulted in changing strategies to accumulate such resources. Shari' a by-laws on zakat and other issues are an expression of this change.

\section{Acknowledgments}

I would like to thank John T. Sidel, R. William Liddle, Alfred C. Stepan, Marcus Mietzner, Gerry van Klinken, Michael Peletz and two anonymous reviewers for their helpful comments on earlier drafts of this article. Discussions with participants of two seminars at the EuroSEAS 2007 Conference in Naples and the Asia Research Institute (ARI) at the

45 The prevalence of money politics as such indicates that there has not been a consolidation of political competition in the districts of South Sulawesi. Money politics are a sign of weakness, not of strength, and they usually occur when machine politics are in their infacy. See Erie's (1988, p 21) study on Irish machine politics in nineteenth century America for a more elaborate categorization of different stages of machine politics. 
National University of Singapore provided me with further useful contributions. I am also grateful to Ina Parenrengi for her research assistance in South Sulawesi, Endah Asnari for her research assistance in Jakarta and the Freedom Institute for providing me with an office in Indonesia. Grants from the Zangger-Weber Foundation, the Weidmann Foundation, the Thyll-Duer Foundation, the Sir Karl Popper Foundation and the Husmann Foundation, all based in Switzerland, made research in Indonesia possible. All errors remain my sole responsibility.

\section{References}

Alfitri (2006), 'The law of zakat management and non-governmental zakat collectors in Indonesia', International Journal for Not-for-Profit Law, Vol 8, No 2, pp 57-66.

Amal, I. (1992), Regional and Central Government in Indonesian Politics: West Sumatra and South Sulawesi 1949-1979, Gadjah Mada University Press, Yogyakarta.

Amin Syam (2007), personal communication, 1 November.

Aspinall, E. (2007), 'From Islamism to nationalism in Aceh, Indonesia', Nations and Nationalism, Vol 13, No 2, pp 245-263.

Aspinall, E. (2008), 'The politics of Islamic law in Aceh', Journal of Asian Studies (forthcoming).

Azwar Hasan (2006), personal communication, 7 September.

Badan Pusat Statistik (BPS) Sulawesi Selatan (2001), Sulawesi Selatan Dalam Angka 2001, BPS, Makassar.

Badan Pusat Statistik (BPS) Sulawesi Selatan (2004), Sulawesi Selatan Dalam Angka 2004, BPS, Makassar.

Badan Pusat Statistik (BPS) Sulawesi Selatan (2005), Kabupaten Bulukumba Dalam Angka 2005/2006, BPS, Makassar.

Bagian Kepegawaian Kota Makassar (2007), 'Rekap Data Pegawai Negeri Sipil Pemerintah Daerah Kota Makassar Keadaan Bulan Januari 2007 per Tlg. 23 Jan. 07', unpublished document.

Bayart, J.-F. (1999), 'The "social capital" of the felonious state', in Bayart, J.-F., Ellis, S., and Hibou, B., eds, The Criminalization of the State in Africa, James Currey, Oxford.

Bendaharawan Kabupaten Barru (2006a), Biaya Honor Guru Mengaji Kabupaten Barru Bulan Januari Sampai Dengan Juni 2006, Tahun Anggaran 2006, Sesuai Daftar Terlampir, Kantor Bupati, Barru.

Bendaharawan Kabupaten Barru (2006b), Biaya Insentif Pegawai Syara SeKabupaten Barru Bulan Januari Sampai Dengan Juni 2006, Tahun Anggaran 2006, Sesuai Daftar Terlampir, Kantor Bupati, Barru.

Bendaharawan Kabupaten Barru (2006c), Biaya Insentif Imam Masjid SeKabupaten Barru Bulan Januari Sampai Dengan Juni 2006, Tahun Anggaran 2006, Sesuai Daftar Terlampir, Kantor Bupati, Barru.

Buehler, M. (2007), 'Local elite reconfiguration in post-New Order Indonesia: an analysis of the 2005 elections of regents', Review of Indonesian and Malaysian Affairs, Vol 41, No 1, pp 119-147.

Buehler, M., and Johnson Tan, P. (2007), 'Party-candidate relationships in Indonesian local politics: a case study of the 2005 regional elections in Gowa, South Sulawesi province', Indonesia, Vol 84, October, pp 41-69.

Bush, R. (2007), 'Regional “shari' ah" regulations in Indonesia: anomaly or symptom?' 
paper presented at the Indonesia Update Conference 2007, Islamic Life and Politics, 7-8 September, Coombs Lecture Theatre, Australia National University, Canberra.

Davis, N. J., and Robinson, R. V. (2006), 'The egalitarian face of Islamic orthodoxy: support for Islamic law and economic justice in seven Muslim-majority nations', American Sociological Review, Vol 71, No 2, pp 167-190.

Erie, S. P. (1988), Rainbow's End: Irish-Americans and the Dilemmas of Urban Machine Politics, 1840-1985, University of California Press, Berkeley, CA.

Fajar (2006), 'Pemkab Kucurkan Rp 397 Juta', 19 June, p 32.

Fajar (2006), '191 CPNS Umum Ikut Tes Mengaji', 4 July, p 29.

Fajar (2007), 'THM Akan Dipungut Zakat Oleh Admin', 5 July, available from Website: http://www.fajar.co.id/news.php?newsid=37117 (accessed 13 November 2007).

Fajar (2007), 'Perda Zakat Dievaluasi Usai Lebaran', 4 October, available from Website: http://www.fajar.co.id/news.php?newsid=42024 (accessed 14 November 2007).

Fealy, G. (2002), 'Radical Islam in Indonesia', conference paper prepared for the From Terrorism to Revolution - The Jihadist Threat to Regime Survival in Societies: Historical Cases and Current Prospects Conference, 22 November, Washington, DC.

Gade, A. M. (2004), Perfection Makes Practice: Learning, Emotion, and the Recited Qur'an in Indonesia, University of Hawai'i Press, Honolulu.

Ilham Arief Sirajuddin (2007), personal communication, 31 October.

Kamrir Daeng Mallongi (2006), personal communication, 28 November.

Kitschelt, H., and Wilkinson, S. I., eds (2007), 'Citizen-politician linkages: an introduction', in Patrons, Clients, and Policies: Patterns of Democratic Accountability and Political Competition, Cambridge University Press, Cambridge.

KPPSI (2005), Ikhtiar Menuju Darusslam: Perjuangan Menegakkan Syariat Islam di Sulawesi Selatan, Pustaka AR-Rayhan, Jakarta.

KPUD Barru (2005), Rekapitulasi Penghitungan Suara Pemilihan Kepala Daerah Dan Wakil Kepala Daerah Tingkat Kabupaten, KPUD, Barru.

Laporan Pengurus BAZ Kabupaten Barru (2006), Tentang Pendistribusian/Pengalokasikan Dana ZIS Tahun 2006M/1427H, Badan Amil Zakat, Barru.

Malley, M. (1999), 'Resource distribution, state coherence, and political centralization in Indonesia 1950-1997', unpublished PhD thesis, University of Wisconsin-Madison, WI.

McGibbon, R. (2006), 'Indonesian politics in 2006: stability, compromise and shifting contests over ideology', Bulletin of Indonesian Economic Studies, Vol 42, No 3, pp 321-340.

Mulia, S. M. (2006), 'Perda Syariat Dan Peminggiran Perempuan: Ada Apa Dengan Demokrasi di Indonesia?' available from Website: http://www.icrp-online.org/ wmview.php?ArtID=178 (accessed 5 August 2007).

Patabai Pabokori (2005), Mengawal Bulukumba Ke Gerbang Syariat Islam, Karier Utama, Makassar.

Patabai Pabokori (2006), personal communication, 14 September.

Pedoman Rakyat (2006), 'Diklat Berubah dengan Nuansa Religius', 31 July, p 19.

Peraturan Kabupaten Daerah Bulukumba Nomor 2 Tahun (2003), Pengelolaan Zakat Profesi, Infaq dan Sadaqah Dalam Kabupaten Bulukumba, Lembaran Daerah Kabupaten Bulukumba Tahun 2003 Nomor 02 Seri C Nomor 01, Bulukumba.

Peraturan Kabupaten Daerah Bulukumba Nomor 5 Tahun (2003), Berpakaian Muslim dan Muslimah Di Kabupaten Bulukumba, Lembaran Daerah Kabupaten Bulukumba Tahun 2003 Nomor 05 Seri C Nomor 03, Bulukumba.

Peraturan Kabupaten Daerah Bulukumba Nomor 6 Tahun (2003), Pandai Baca Al-Qur'an Bagi Siswa dan Calon Pengantin Dalam Kabupaten Bulukumba, Lembaran Daerah Kabupaten Bulukumba Tahun 200306 Seri C Nomor 04, Bulukumba.

Peraturan Daerah Kota Makassar Nomor 5 Tahun (2006), Tentang Pengelolaan Zakat, Bagian Hukum Sekretariat Kota Makassar, Tahun. 
Peraturan Walikota Makassar Nomor 3 Tahun (2007), Tentang Pembentukan Susunan Organisasi Dan Tata Kerja Badan Amil Zakat Kota Makassar, Berita Daerah Kota Makassar, Tahun.

Rum, M. (2006), personal communication, 28 November.

Salim, A. (2003), 'Zakat administration in politics of Indonesian New Order', in Salim, A., and Azyumardi Azra, eds, Shari'a and Politics in Modern Indonesia, ISEAS, Singapore.

Scott, J. (1972), Comparative Political Corruption, Prentice Hall, Upper Saddle River, NJ.

Sidel, J. T. (1999), Capital, Coercion, and Crime: Bossism in the Philippines, Stanford University Press, Stanford, CA.

Syafruddin Nur (2005), Campaign stickers.

Tempo (1972), 'Menata Pelita di Sulawesi Selatan', 19 February, pp 43-50.

Tentang Pembentukan Unit Pengumpul Zakat - UPZ (2007), Instruksi Walikota Makassar Nomor 02/45112.05/Inst/2007, Kota Makassar, Makassar.

Tribun Timur (2006), 'KPPSI: Perda Miras Harus Melarang Total', 3 July, p 30.

Tribun Timur (2006), 'PS Daerah', 28 July, p 17.

Warta Perundangan (1999), 'Undang-Undang No. 38 Tahun 1999 Tentang Pengelolaan Zakat', 18 October, p 1.

Wheeler, M. (2007), 'Consultancy on issues in health financing', unpublished document, German Technical Cooperation (GTZ), Jakarta.

World Bank (2007), 'Indonesia: sharia and regional autonomy', unpublished draft paper, World Bank, Washington, DC. 